\title{
Reproduction of Varroa destructor does not elicit varroa sensitive hygiene (VSH) or recapping behaviour in honey bee colonies (Apis mellifera)
}

\author{
Lina SPRAU ${ }^{1}{ }^{1}$, Martin HaSSELMANN ${ }^{1}$, and Peter RosenKRANZ ${ }^{2}$ \\ ${ }^{1}$ Department of Livestock Population Genomics, Institute of Animal Science, University of Hohenheim, Stuttgart, \\ Germany \\ ${ }^{2}$ Apicultural State Institute, University of Hohenheim, Stuttgart, Germany
}

Received 23 February 2021 - Revised 24 June 2021 - Accepted 30 July 2021

\begin{abstract}
Suppressed mite reproduction (SMR) is an important trait for the selection of Varroa resistant honey bee colonies. It has repeatedly been assumed that SMR is an effect of varroa sensitive hygiene (VSH) when hygienic bees preferably remove those brood cells where the mite has reproduced. We here compare the VSH behaviour of honey bees toward brood cells artificial infested with a varroa mite. By infesting half of the brood cells directly after the cell capping and the other half only $24 \mathrm{~h}$ later, we established two groups with high (>75\%) and low $(<2 \%)$ mite reproduction. After 8 days, about $40 \%$ of the infested brood cells were removed, however without any difference between both groups. Likewise, no group differences were recorded in the percentage of recapped brood cells. This strongly indicates that the presence of mite offspring is not a crucial trigger for the VSH behaviour. SMR data like the percentage of non-reproducing mites are therefore not the optimal measure for the selection of colonies with high VSH.
\end{abstract}

VSH / varroa destructor / varroa resistance / recapping / SMR / selection protocol

\section{INTRODUCTION}

The ectoparasite Varroa destructor of the honey bee (Apis mellifera) represents the main cause of periodical colony losses and is therefore still the greatest threat for global beekeeping (Genersch et al. 2010; Le Conte et al. 2010; Traynor et al. 2020). Currently, the survival of managed honey bee colonies depends essentially on the periodic application of effective mite control measures by the beekeepers. There are a wide range of chemical acaricides and biotechnical control methods available which can

Corresponding author: L. Sprau,

lina.sprau@uni-hohenheim.de

Manuscript Editor: Yves Le Conte prevent colony losses and reduce the economic damages (Büchler et al. 2020b). However, most beekeeper and scientists agree that yearly treatments cannot be the long-term solution of the varroa mite problem (Dietemann et al. 2012). Chemical treatments often have side effects on bees and brood (Higes et al. 1999; Pietropaoli and Formato 2018; Strachecka et al. 2012), can leave residues in hive products (Floris et al. 2004; Lodesani et al. 1992; Wallner 1999), and the mite can build up resistance against varroacidal compounds (Elzen et al. 2000; Milani 1999). The establishment of varroa tolerant or resistant honey bee colonies is considered as the long-term and sustainable alternative to otherwise continuous treatments. The so far applied approaches included natural selection 
(Blacquière et al. 2019; Fries et al. 2006; Locke et al. 2012; Oddie et al. 2017; van Alphen and Fernhout 2020) as well as selective breeding programs performed all over the world (Kovačić et al. 2020; Mondet et al. 2020b).

Although a stable varroa tolerant breeding line is not yet completely established and commercially available, some breeding programs show promising steps towards resistant honey bee colonies. "Resistant" is here defined as a mechanism which reduces the fitness of the parasite (i.e. reproductive success) to keep the population below a damaging threshold (Horns and Hood 2012; Mondet et al. 2020b). Unfortunately, targeted selection is complicated by the fact that there are several mechanisms that contribute to varroa resistance in honeybees. This includes features on the colony level like frequent swarming or small colony size (Loftus et al. 2016) and mechanisms to reduce the reproductive success of the mite like suppressed mite reproduction (SMR), varroa sensitive hygiene (VSH), and recapping (REC).

SMR, VSH, and REC are currently the most thoroughly investigated traits and have already been used in several selection projects (Büchler et al. 2020a; Kirrane et al. 2014; Kovačić et al. 2020; Mondet et al. 2020a; Rinderer et al. 2010). $\mathrm{VSH}$ is an active behavioural mechanism of the adult bee. Bees expressing this trait show a pronounced recognition of mite infested brood cells leading to a higher removal rate of varroa-infested brood (Harbo and Harris 2005; Harris 2007). The removal of infested brood cells has been considered as crucial factor for mite resistance (Boecking and Ritter 1993; Spivak 1996; Spivak and Danka 2020). In general, SMR describes the occurrence of a higher proportion of non-reproductive mites whereas the mechanisms are yet unknown (Harbo and Harris 1999, 2005). Recapping is an opening and re-closing of the cell cap of mite infested brood cells_-probably performed by different cohorts of adult bees. This might disturb the course of mite reproduction; however, the importance of recapping as a mechanism of mite resistance is still under debate (Martin et al. 2020; Oddie et al. 2018; van Alphen and Fernhout 2019).
So far, neither the mechanisms of SMR nor the signals that trigger VSH are sufficiently understood. However, there are indications that both traits might be two sides of the same coin: In 1999, Harris and Habro observed a higher number of nonreproductive mites in some colonies and called it initially supressed mite reproduction (Harbo and Harris 1999). Later on, the high proportion of nonreproductive mites was connected with the preferred removal of varroa-infested brood cells where the mite had started to reproduce (Harbo and Harris 2005; Harris 2007). Therefore, "non-reproduction" of varroa mites could be both, the effect of SMR and the effect of VSH. However, it was shown that VSH cannot explain all cases of SMR (Ibrahim and Spivak 2006). SMR is likely triggered by properties of the larvae and/or pupae (Garrido and Rosenkranz 2003), while VSH is a behavioural trait of the adult bee. Because SMR can be an indirect result of VSH behaviour, the terminology of SMR and VSH has become indistinct (Harris et al. 2012), especially in applied selection programs.

Therefore, some breeding programs still use a SMR evaluation protocol, where both traits, SMR and VSH, are supposed to be analysed together (Büchler et al. 2017; Mondet et al. 2020a; Villa et al. 2009). According to this protocol, the ratio of non-reproductive mites to reproductive mites is used to calculate the SMR value. The SMR value is often directly transferred to a VSH Value, due to the assumption that VSH can be detected by the reproduction of the mite because the adult bees preferably remove reproductive mites in a 3:1 ratio (Harris et al. 2012). The premise behind the calculation is also a normal occurrence of up to $25 \%$ of non-reproductive mites in a beehive (Fuchs 1994; Martin 1994; Martin et al. 1997) and the assumption that VSH is primarily correlated to SMR which than allows a comparable calculation. Furthermore, the observation of fewer reproductive mites in a for $\mathrm{VSH}$ selected colony let to the statement that VSH is triggered by the presences of mite offspring (Harris et al. 2012).

This study closely examines the removal behaviour of adult bees towards cells infested by reproductive and non-reproductive mites, in order to 
distinguish the effect of the reproductive status of the mite on the removal behaviour of the adult bees by a direct comparison. This allows a clarification of the trigger behind VSH and helps to further differentiate between the two behavioural traits SMR and VSH. REC was documented as an additional mechanism of behaviour to analyse the correlation of recapping and reproductive status of the mite.

Consequently, the focus of this study were the following questions:

1. Does the reproduction status of the mite elicit the removal rate of the bees?

2. Is the recapping behaviour correlated with the reproduction status of the mite?

3. Is the SMR protocol a useful tool to analyse the VSH trait?

\section{METHOD}

\subsection{Experimental colonies}

This experiment was conducted with 13 Apis mellifera colonies. These colonies were provided from a varroa resistant breeding program in Southern Germany and were randomly selected out of all the colonies within the breeding program that show values higher than $75 \% \mathrm{VSH}$ in a previous evaluation using the SMR protocol (Büchler et al. 2017). Four colonies were managed in MiniPlus systems and the other nine in one-story Zander hives; however, all colonies contained at least 5000 bees during the experiments. Pre-selected colonies were chosen based on the expectation that they show a removal rate greater than average. Consequently, we expected a higher probability to see an impact i.e. of the removal of varroa-infested brood and therefore achieve a higher comparability of both groups.

\section{ARTIFICIAL MITE INTRODUCTION}

Artificial infestation was chosen as the method to analyse brood removal rates. This method allows for a direct way to quantify the removal of mite-infested brood. Three categories were analysed: (i) Mites placed in freshly capped cells (freshly capped cells $=$ FCC) none older than $6 \mathrm{~h}$ to produce reproductive mites. (ii) Mites introduced into cells that were capped at least $24 \mathrm{~h}$ but no longer than $30 \mathrm{~h}$ (Frey et al. 2013; Rosenkranz and Garrido 2004) (24 h capped cells $=24 \mathrm{HCC}$ ) to artificially creating nonreproductive mites. Mites placed in cells which are capped for longer than $24 \mathrm{~h}$ do not start oogenesis and therefore do not reproduce. This way of creating non-reproductive mites gives a unique opportunity to compare the direct impact of reproductive to non-reproductive mites. (iii) For the control group, cells were opened and closed in the same manner without introducing a mite. The mites were obtained by the sugar shake method (Dietemann et al. 2013) and introduced into the cell by making a small incision in the cell cap with a scalpel. Each mite was placed on a brush and gently placed close to the opened cell. After the mite walked inside the cell, the cell cap was closed again. All artificial infestation procedures were performed by one trained person to eliminate the skill level as an impacting factor. The cells were randomly chosen on both sides of one broodcomb. After introducing the mites, the broodcomb was positioned back into the hive and analysed after a period of 8 days, as the highest removal of brood cells occurs after 5 days (Harris 2007).

In the nine colonies in Zander systems, 20 randomly positioned cells were chosen for each category (FCC, 24HCC, C). For seven colonies, the experiment was repeated three times during a timeframe of 6 weeks. Two colonies could only be infested once. In total, 1.397 mites were individually used for these infestations. In two repetitions of measurements, the cell cover was checked for signs of recapping. Recapping behaviour can be seen by the presence of the cocoon on the inside of the cell cap (Oddie et al. 2018). In the four colonies managed in MiniPlus, 30 cells per group were infested and the experiment was repeated 2 times in 4 weeks. During the experiment the status of the cell, the pupae, the mites and the reproduction success of the mite were documented. 


\section{STATISTICS}

The statistical analysis was calculated with the statistics program jmp pro version 15.1.0. Mixed models (MM) were designed with brood removal rate (\%) or recapping activity (\%) as variables and the reproduction status as a fixed effect, the colony, the hive system, and repetition of experiments as random effects. The normal distribution of the residuals in every model was confirmed (Shapiro -Wilk-Test), by rejecting the null hypothesis. The three groups were compared with a multiple comparison test (Tukey HSD all pairwise comparison). The removal rate is the number of open cells divided by the total number of infested cells. A cell with a removed cell cap but still intact pupae was counted as opened and (possible) recapped; this scenario was observed in total in 6 brood cells. Partially recapped cells were classified as recapped if the diameter was bigger than an average size of a mite. The rate of recapping activity was calculated as recapped cells observed divided by total number of remaining closed cells.

\section{RESULTS}

From 698 mites that were introduced into freshly capped brood cells (FCC), 238 were still present and alive 8 days after the artificial infestation. From those mites, $75.4 \pm 25.7 \%$ were reproductive and produced offspring (Figure 1). From these reproductive mites, $97 \pm 11 \%$ revealed successful reproduction defined by the presence of minimum one male and one female offspring in the same cell. The average number of offspring (in case offspring accrued) was $2.9 \pm 1.0$ mites per cell. In the category of the delayed introduced mites (24HCC), $2.7 \pm 3.3 \%$ of living mites produced a single female offspring (8 out of 294 cells); in 20 brood cells, a male offspring was produced $(6.8 \pm 6.4 \%)$; and further only in 4 out of 294 brood cells $(1.36 \%)$ with a living mother mite, one male and one female protonymph were present simultaneously. The average number of offspring (in case offspring accrued) was $1.2 \pm 0.4$ mites per cell.

In the control group without artificial mite introduction (C), in a total of 700 brood cells,

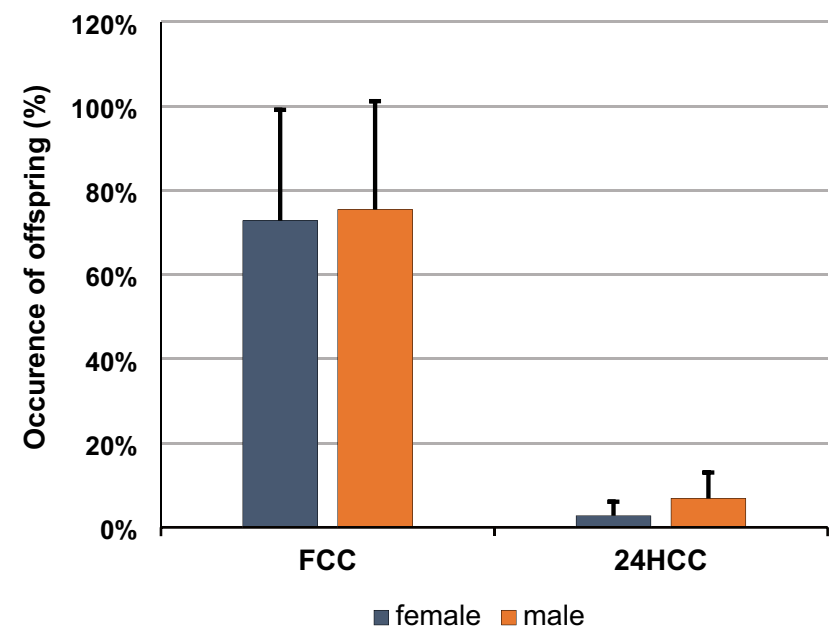

Figure 1. Occurrence of female and male offspring of varroa mites either introduced in freshly capped brood cells (FCC) or in brood cells $24 \mathrm{~h}$ after capping (24HCC). ( $N=1397$ brood cells; $N=13$ colonies). Data are presented in mean percentage with standard deviation (SD). 
only naturally invaded 18 mites were found. Due to the random selection of cells, it could not be guaranteed that there was not already a mite present in the cell. In those 18 cases, offspring was present in $77.8 \pm 38.2 \%$.

Out of the 819 remaining closed cells, 95 cells (FCC) and 72 cells (24HCC) contained no mite at the time of evaluation.

Concerning the hygienic behaviour, the mixed model did not reveal any significant impact of the two hive systems which were included as random factor $(p=0.6907)$. Therefore, the data of both hive systems were pooled in the respective figures. The average removal of brood from the FCC group with largely reproducing mites did not significantly differ to the brood removal of the non-reproductive mites of the $24 \mathrm{HCC}$ group $(41.0 \pm 23.5 \%$ vs. $39.6 \pm 15.8 \%$; MM, Tukey HSD all pairwise comparison; $p=0.843$; Figure 2). The brood removal rate in the control group $(7.8 \pm 7.3 \%)$ was significantly lower compared to the other both groups $(p<0.001)$.

The recapping behaviour was recorded in 8 colonies in two repeated measurements (one colony could only be measured once), revealing $52.0 \pm 25.1 \%$ recapping events in FCC cells and
$49.5 \pm 30.4 \%$ in $24 \mathrm{HCC}$ cells without significant difference between the groups (Figure 3; MM, Tukey HSD all pairwise comparison; $p=0.958$ ). Also, the control cells were recapped at relatively high frequencies, however significantly lower compared to the two other groups (Figure 3; MM, Tukey HSD all pairwise comparison; FCC$\mathrm{C}: p=0.0244$; 24HCC-C: $p=0.0181$ ). Recapping activity occurred in a range from 6 to $100 \%$ throughout all groups and colonies, explaining the high standard abbreviations.

\section{DISCUSSION}

Varroa sensitive hygiene (VSH) is considered as a trait with high potential in selecting and breeding for varroa resistant honey bees. However, the identification and quantification of this behaviour are difficult and extremely time-consuming. As a result, some selective breeding programs use the SMR (supressed mite reproduction) protocol with the mite reproduction ratio as a quantification and validation of $\mathrm{VSH}$, assuming that honey bees with high VSH preferentially remove infested brood cells with

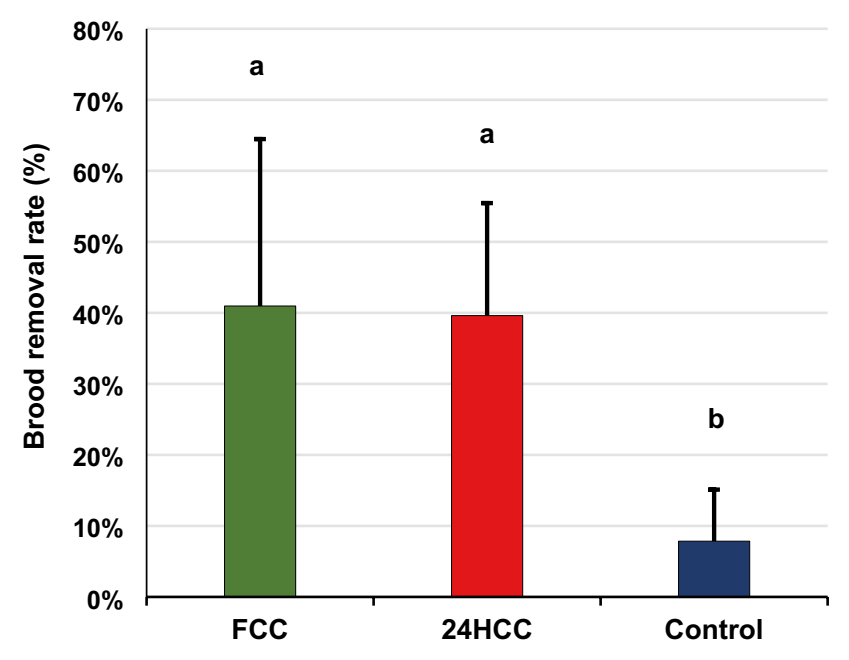

Figure 2. Brood removal rates in brood cells artificially infested with one mite (FFC and 24HCC, explanation see Figure 1) and non-infested control cells. Brood removal rates ( $n=13$ colonies; 20-30 cells per colony and category (FCC, 24HCC, C) manipulated) presented as means with SD. The letters indicate significant differences $(p<0.001)$, calculated with a mixed model. 


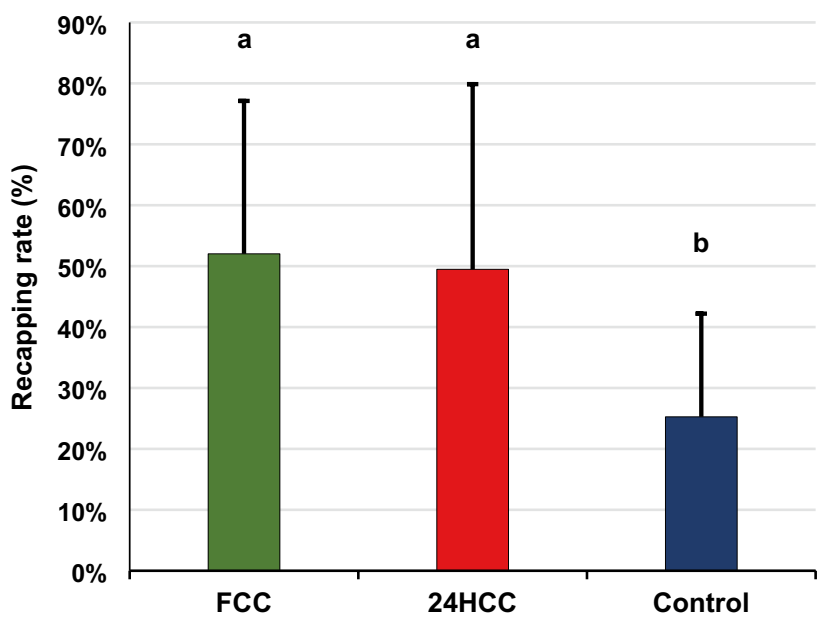

Figure 3. Recapping rates in varroa infested brood cells with normal reproduction (FCC), brood cells without varroa reproduction $(24 \mathrm{HCC})$ and with non-infested control cells, presented as means with SD. The letters indicate the significance level $(p<0.05)$, calculated with a mixed model.

reproducing mites (Danka et al. 2011; Harbo and Harris 2005; Ibrahim and Spivak 2006). A high percentage of non-reproductive mites is therefore considered as a value for VSH (Harris et al. 2012). Briefly, the SMR protocol requires beehives with brood combs containing unsealed brood of the 5th larval instar. These colonies are infested by placing 100-150 adult female mites on top of the hive. About 7-9 days post capping of these brood cells, the respective combs are analysed for mite infested cells and for the presence of mite offspring and the ratio of reproducing to non-reproducing mites provide the basis for the VSH value (Büchler et al. 2017; Mondet et al. 2020a). However, this method does not allow a clear differentiation between VSH and SMR. The artificial infestation of brood cells represents the only method that allows a direct examination of the brood removal behaviour of the bees towards infested cells in comparison to non-infested control cells. Here, a particular mode of the artificial infestation enabled us in addition the "production" of non-reproductive mites and therefore a direct comparison of the removal behaviour of the bees toward brood cells with reproducing vs. non-reproducing mites. Garrido et al. (2000) and Frey et al. (2013) showed that a mite introduced into a cell capped for at least $24 \mathrm{~h}$ does not start the oogenesis and therefore does not produce offspring. This experiment clearly confirms these results. In $<10 \%$ of the cells, the introduced mites had one single offspring, and in only 4 out of 294 cases both a male and a female offspring were simultaneously in one cell. The fact that in all these cases only protonymphs or eggs were recorded 8 days after the artificial infestation indicate a delayed start of reproduction. The smell and behaviour of the mite within the brood cells were not analysed; therefore, a different smell or activity of the artificially generated non-reproductive mites cannot be excluded and should be considered in future experiments. In contrast, the female mites which were introduced in freshly capped cells exhibited with about $75 \%$ reproducing mites and an average of three progenies per cell a reproductive success similar to that of naturally invaded mites (Fuchs 1994; Martin 1994; Martin et al. 1997; Oddie et al. 2018). This confirms that the here used artificial infestation had no negative impact on the reproductive ability of the mites. The relatively high rate of $25 \%$ non-reproducing mites in the category of FCC could be influenced by the recapping behaviour expressed in those colonies, because a recent study showed that recapping behaviour is correlated with a reduced 
reproductive success of the mites (Oddie et al. 2021). Even more important, the infestation of brood cells of different age created two distinct groups of varroa infested brood cells, one with a normal reproductive rate and one with a negligible number of mite offspring.

Despite this huge difference in mite reproduction, no differences in the brood removal rates were observed when both cell groups were offered simultaneously in the same colonies. Thus, our results are in clear contradiction to the above mentioned assumption, that the offspring of the mite within the sealed brood cells is a crucial trigger for the VSH behaviour (Harbo and Harris 2005; Harris et al. 2012). The reproductive status of the mite had obviously no impact on the decision of the adult bees to remove a mite infested brood.

The removal rate of the control cells of about $8 \%$ indicates that even the opening and closing of the cell caps had elicited some hygienic behaviour which is shown in other experiments with manipulated cells with removal rates of up to $10 \%$ as well (Spivak 1996; Spivak and Danka 2020; Wagoner et al. 2018). Additionally, a complete absence of mites could not be guaranteed and therefore the few mites present could have triggered removal behaviour in a small scale. However, the fivefold higher removal rate of varroa infested cells confirms that not an unspecific high hygienic sensitivity of these preselected colonies but rather a varroa-specific hygienic behaviour was responsible for the recorded differences.

Therefore, in our experiments, the presence of the mite within the brood cell was crucial for the recorded high brood removal rate, whereas the removal rate is independent from the presence of offspring. However, the occurrence of multiple foundress females within one brood cell seems to enhance the VSH behaviour (Kim et al. 2018), indicating that the adult mite represents the source for the removal stimulus. The actual trigger of the hygienic behaviour and in particular of VSH is still being discussed. It is likely that chemical cues of the mite play a role (Martin et al. 2002; Mondet et al. 2016). This was confirmed in a recent study from Mondet et al. (2021) who identified 6 varroaparasitization-specific compounds from mites and parasitized pupae that trigger VSH. The relationship between the total amount of the six VPS compounds per cell and the number of mite offspring per cell could mean that even a small amount of the VPS compounds-deriving exclusively from the mother mite-is sufficient to trigger removal behaviour. In addition to these chemical cues, behavioural stress signals of the host larvae or pupae elicited by the parasitization of the mite (Nazzi et al. 2004; Wagoner et al. 2018, 2019), or signs of disease caused by infections through the transmitted viruses (Schöning et al. 2012) could contribute to the removal behaviour. Our study can at least exclude that signals deriving from the mite's offspring (Harris et al. 2012) are the crucial trigger for VSH. This supports similar results of Eynard et al. (2020), who could not find any correlation of VSH and SMR, when both traits are quantified successively within the same colony. Recently, the term mite non-reproduction (MNR) was suggested to clarify a so far imprecise definition by distinguish between a trait exclusively originating from features of the brood (SMR) and the overall occurrence of non-reproductive mites (MNR; Eynard et al. 2020; Mondet et al. 2020a, b) Therefore, MNR can be a result of traits like VSH, while SMR is a trait solely originating from inhibiting or stimulating brood signals. This means MNR is an umbrella term to describe the occurrence of non-reproductive mites when the trigger or origin is not clear. Our results have consequences for the evaluation of some commonly used protocols for the selection of colonies with high VSH values. The SMR protocol (Büchler et al. 2017; Mondet et al. 2020a) was created to evaluate a large number of colonies in a short period of time and with the intention to involve beekeeper in this process. For those reasons, the SMR protocol is used in breeding programs for VSH evaluations as well, with the assumption that the SMR value can be directly translated to the VSH value. Therefore, the analysis of the percentage of reproducing mites in brood combs seems to be a relatively easy and manageable parameter for the evaluation of an VSH score (Harris and Harbo 2000; Villa et al. 2009). However, according to our results, the mite reproduction rate represents a selection parameter exclusively for SMR 
and not for VSH, establishing mite reproduction therefore not as a suitable measure for directly breeding VSH. The success of some SMR studies which resulted in good VSH colonies show that there might be a link between VSH and high percentages of non-reproductive mites, probably because female mites are generally more disturbed in hygienic colonies. However, VSH is just one factor which might promote higher percentages of non-reproductive mites (SMR). Therefore, the selection of VSH via SMR protocol is indirect at best. Consequently, we need to carefully distinguish between these two terms. This is of particular importance for experimental approaches with the aim to identify genetic markers for the VSH trait. Colonies that are used for the expression analysis of VSH-related genes should be selected exclusively by a direct analysis of the removal of varroa infested brood cells (Mondet et al. 2020b). If the phenotypic expression is not solely focused on VSH, the identification of VSH-related gene activities may become difficult or even impossible. The selective breeding of varroa resistant stocks might finally require more than one resistant traits; however, for the understanding of the individual traits and for a targeted selection, each parameter must first be analysed separately with suitable methods. In the case of VSH, the artificial infestation of individual brood cells with female mites seems to be the method of choice because it provides data on both the VSH and the SMR trait. However, this method requires trained personal and cannot be easily implemented on a larger scale. Nonetheless, the results generated by this method are more precise and reflect the accurate value of VSH. We therefore recommend to invest effort in the training of technicians and beekeeper for the use of this method rather than screening large numbers of colonies with uncertain result, if the focus of the study is exclusively on VSH.

The number of cells targeted by recapping behaviour did also not differ between reproductive vs. non-reproductive cells. Recapping is the opening and resealing of holes in the cell cap and is considered to be the first step in the hygienic behaviour. Such holes facilitate the access to volatile cues of suspicious cells leading to the decision to either remove infested brood or to recap the cell with healthy brood (Martin et al. 2020). Recapping seems to be a behaviour common in all colonies in different degrees, even in colonies not specially bred for varroa resistance (Kirrane et al. 2014; Oddie et al. 2018; Spivak and Danka 2020). This also explains why the non-infested control cells revealed a relatively high percentage of about $25 \%$ recapped cells compared to approximately $50 \%$ of the infested brood cells. Whether the manipulation of the cell caps in the control group contributed to this recapping rate should be analysed in additional experiments. In any case, the recapping behaviour provides an opportunity for the mite to escape the cell, which likely has contributed to the high number of cells where the introduced mite disappeared. In this study, however, the results of the recapping activity of cells with or without reproduction are so similar that the presence of mite offspring is also not a trigger for the recapping activity. The results also raise the question why bees recap cells that still contain mites and do not remove the pupae when the cell is already in inspection. Possible explanations are that the signal from the pupae was not strong enough, that the mite somehow manages to hide, that volatile compounds of the mites are released from the open cell so that the brood appears to be "normal," or that the bee that recap the cell was not as sensitive to the signal as the predecessor that opened the cell (Martin et al. 2020).

The removal of varroa infested brood disturbs the reproduction cycle of the mite and can therefore prevent an exponential growth of mite population and keep the infestation rate under a damaging threshold (Danka et al. 2012; Kirrane et al. 2018; Villa et al. 2009). In conclusion, VSH is a promising trait for further use in selection programs when accurate methods like artificial infestation of brood cells are used.

\section{ACKNOWLEDGEMENTS}

We want to thank Gerhard Kottek and all the other members of the Baden-Württemberg breeding project SETBie and Stefan Luff from the Bavarian breeding project for the organization of the beehives used in these experiments. Thanks also belong to Karsten Schweikert from the Data and Statistical Consulting of the University of Hohenheim for the statistical advice and our colleagues 
Melanie Liebsch and Carolin Rein for the support and help during the year.

\section{AUTHOR CONTRIBUTION}

All authors designed the experiment, participated in interpretation of the data, wrote, read, and approved the final manuscript. LS performed the experiments and analysis.

\section{FUNDING}

Open Access funding enabled and organized by Projekt DEAL. The SETBie - Project (Selection and Establishment of varroa resistant honey bees in Baden-Württemberg) is funded by the European Innovation Partnership (EIP) and supported by the European Agricultural Fund for Rural Development (EAFRD).

\section{AVAILABILITY OF DATA AND MATERIAL}

The datasets generated during and/or analysed during the current study are available from the corresponding author on reasonable request.

Code availability Not applicable.

\section{DECLARATIONS}

Ethics approval Not applicable.

Consent to participate Not applicable.

Consent for publication Not applicable.

Conflict of interest The authors declare no competing interests.

Open Access This article is licensed under a Creative Commons Attribution 4.0 International License, which permits use, sharing, adaptation, distribution and reproduction in any medium or format, as long as you give appropriate credit to the original author(s) and the source, provide a link to the Creative Commons licence, and indicate if changes were made. The images or other third party material in this article are included in the article's Creative Commons licence, unless indicated otherwise in a credit line to the material. If material is not included in the article's Creative Commons licence and your intended use is not permitted by statutory regulation or exceeds the permitted use, you will need to obtain permission directly from the copyright holder. To view a copy of this licence, visit http://creativecommons.org/licenses/ by $/ 4.0 \%$.

\section{REFERENCES}

Blacquière T, Boot W, Calis J, Moro A, Neumann P, Panziera D (2019) Darwinian black box selection for resistance to settled invasive Varroa destructor parasites in honey bees. Biol Invasions 21:25192528. https://doi.org/10.1007/s10530-019-02001-0

Boecking O, Ritter W (1993) Grooming and removal behaviour of Apis mellifera intermissa in Tunisia against Varroa jacobsoni. Journal of Apicultural Research 32:127134. https://doi.org/10.1080/00218839.1993.11101297

Büchler R, Costa C, Mondet F, Kezić N, Kovačić M (2017) Screening for low Varroa mite reproduction (SMR) and recapping in European honey bees. https://dev.rescol.org/rnsbbweb/wp-content/uploads/ 2017/11/RNSBB_SMR-recapping_protocol_2017_ 09_11.pdf. Accessed 25 November 2020

Büchler R, Kovačić M, Buchegger M, Puškadija Z, Hoppe A, Brascamp EW (2020a) Evaluation of Traits for the Selection of Apis Mellifera for Resistance against Varroa Destructor Insects 11 https://doi.org/10.3390/insects 11090618

Büchler R, Uzunov A, Kovačić M, Prešern J, Pietropaoli M, Hatjina F, Pavlov B, Charistos LG, Formato L, Galarza E, Gerula D, Gregorc A, Malagnini V, Meixner M, Nedić N, Puškadija Z, Rivera-Gomis J, Rogelj Jenko M, Smodiš Škerl MI, Vallon J, Vojt D, Wilde J, Nanetti A, (2020) Summer brood interruption as integrated management strategy for effective Varroa control in Europe Journal of Apicultural Research 59:764-773 https://doi.org/10.1080/00218839.2020.1793278

Danka RG, Harris JW, Villa JD (2011) Expression of Varroa sensitive hygiene (VSH) in commercial VSH honey bees (Hymenoptera: Apidae). J Econ Entomol 104:745-749. https://doi.org/10.1603/ec10401

Danka RG, Harris JW, Villalobos E, Glenn T (2012) Varroa destructor resistance of honey bees in Hawaii, USA, with different genetic proportions of Varroa Sensitive Hygiene (VSH). Journal of Apicultural Research 51:288-290. https://doi.org/ 10.3896/IBRA.1.51.3.13

Dietemann V, Pflugfelder J, Anderson D, Charrière J-D, Chejanovsky N, Dainat B, Miranda J de, Delaplane K, Dillier F-X, Fuch S, Gallmann P, Gauthier L, Imdorf A, Koeniger N, Kralj J, Meikle W, Pettis J, Rosenkranz P, Sammataro D, Smith D, Yañez O, Neumann P (2012) Varroa destructor : research avenues towards sustainable control. Journal of Apicultural Research 51:125-132. https://doi.org/ 10.3896/IBRA.1.51.1.15

Dietemann V, Nazzi F, Martin SJ, Anderson DL, Locke B, Delaplane KS, Wauquiez Q, Tannahill C, Frey E, Ziegelmann B, Rosenkranz P, Ellis JD (2013) Standard methods for varroa research. Journal of Apicultural Research 52:1-54. https://doi.org/10. 3896/IBRA.1.52.1.09 
Elzen PJ, Baxter JR, Spivak M, Wilson WT (2000) Control of Varroa jacobsoni Oud. resistant to fluvalinate and amitraz using coumaphos. Apidologie 31:437-441. https://doi.org/10.1051/apido:2000134

Eynard SE, Sann C, Basso B, Guirao A-L, Le Conte Y, Servin B, Tison L, Vignal A, Mondet F (2020) Descriptive Analysis of the Varroa Non-Reproduction Trait in Honey Bee Colonies and Association with Other Traits Related to Varroa Resistance. Insects 11:492. https://doi.org/10.3390/insects 11080492

Floris I, Satta A, Cabras P, Garau VL, Angioni A (2004) Comparison between two thymol formulations in the control of Varroa destructor: effectiveness, persistence, and residues. J Econ Entomol 97:187-191. https://doi.org/10.1093/jee/97.2.187

Frey E, Odemer R, Blum T, Rosenkranz P (2013) Activation and interruption of the reproduction of Varroa destructor is triggered by host signals (Apis mellifera). Journal of Invertebrate Pathology 113:5662. https://doi.org/10.1016/j.jip.2013.01.007

Fries I, Imdorf A, Rosenkranz P (2006) Survival of mite infested (Varroa destructor) honey bee (Apis mellifera ) colonies in a Nordic climate. Apidologie 37:564-570. https://doi.org/10.1051/apido:2006031

Fuchs S (1994) Non-reproducing Varroa jacobsoni Oud. in honey bee worker cells?status of mites or effect of brood cells? Exp Appl Acarol 18:309317. https://doi.org/10.1007/BF00132320

Garrido C, Rosenkranz P (2003) The reproductive program of female Varroa destructor mites is triggered by its host, Apis mellifera. Exp Appl Acarol 31:269-273. https://doi.org/10.1023/B:APPA. 0000010386.10686.9f

Garrido C, Rosenkranz P, Stürmer M, Rübsam R, Büning $\mathrm{J}$ (2000) Toluidine blue staining as a rapid measure for initiation of oocyte growth and fertility in Varroa jacobsoni Oud. Apidologie 31:559-566. https://doi.org/10.1051/apido:200014

Genersch E, Ohe W von der, Kaatz H, Schroeder A, Otten C, Büchler R, Berg S, Ritter W, Mühlen W, Gisder S, Meixner M, Liebig G, Rosenkranz P (2010) The German bee monitoring project: a long term study to understand periodically high winter losses of honey bee colonies. Apidologie 41:332352. https://doi.org/10.1051/apido/2010014

Harbo JR, Harris JW (1999) Selecting honey bees for resistance to Varroa jacobsoni. Apidologie 30:183-196. https://doi.org/10.1051/apido: 19990208

Harbo JR, Harris JW (2005) Suppressed mite reproduction explained by the behaviour of adult bees. Journal of Apicultural Research 44:21-23. https:// doi.org/10.1080/00218839.2005.11101141

Harris JW (2007) Bees with Varroa Sensitive Hygiene preferentially remove mite infested pupae aged $\leq$ five days post capping. Journal of Apicultural Research 46:134-139. https://doi.org/10.1080/ 00218839.2007.11101383

Harris JW, Harbo JR (2000) Changes in reproduction of Varroa destructor after honey bee queens were exchanged between resistant and susceptible colonies. Apidologie 31:689-699. https://doi.org/10. 1051/apido:2000153

Harris JW, Danka RG, Villa JD (2012) Changes in Infestation, Cell Cap Condition, and Reproductive Status of Varroa destructor (Mesostigmata: Varroidae) in Brood Exposed to Honey Bees With Varroa Sensitive Hygiene. an 105:512-518. https:// doi.org/10.1603/AN11188

Higes M, Meana A, Suárez M, Llorente J (1999) Negative long-term effects on bee colonies treated with oxalic acid against Varroa jacobsoni Oud. Apidologie, 30(4), 289-292. Apidologie 30:289-292. https://doi.org/10.1051/APIDO:19990404

Horns F, Hood ME (2012) The evolution of disease resistance and tolerance in spatially structured populations. Ecol Evol 2:1705-1711. https://doi. org/10.1002/ece3.290

Ibrahim A, Spivak M (2006) The relationship between hygienic behavior and suppression of mite reproduction as honey bee (Apis mellifera ) mechanisms of resistance to Varroa destructor. Apidologie 37:3140. https://doi.org/10.1051/apido:2005052

Kim SH, Mondet F, HERVÉ M, MERCER A (2018) Honey bees performing varroa sensitive hygiene remove the most mite-compromised bees from highly infested patches of brood. Apidologie 49:335-345. https://doi.org/10.1007/ s13592-017-0559-6

Kirrane MJ, Guzman LI de, Holloway B, Frake AM, Rinderer TE, Whelan PM (2014) Phenotypic and genetic analyses of the varroa sensitive hygienic trait in Russian honey bee (hymenoptera: apidae) colonies. PLoS ONE 10:e0116672. https://doi.org/ 10.1371/journal.pone.0116672

Kirrane MJ, Guzman LI de, Whelan PM, Frake AM, Rinderer TE (2018) Evaluations of the Removal of Varroa destructor in Russian Honey Bee Colonies that Display Different Levels of Varroa Sensitive Hygienic Activities. J Insect Behav 31:283297.https://doi.org/10.1007/s10905-018-9672-2

Kovačić M, Puškadija Z, Dražić MM, Uzunov A, Meixner MD, Büchler R (2020) Effects of selection and local adaptation on resilience and economic suitability in Apis mellifera carnica. Apidologie:1-12. https://doi.org/10.1007/ s13592-020-00783-0

Le Conte Y, Ellis M, Ritter W (2010) Varroa mites and honey bee health: can Varroa explain part of the colony losses? Apidologie 41:353-363. https://doi. org/10.1051/apido/2010017

Locke B, Le Conte Y, Crauser D, Fries I (2012) Host adaptations reduce the reproductive success of Varroa destructor in two distinct European honey bee populations. Ecol Evol 2:1144-1150. https:// doi.org/10.1002/ece3.248

Lodesani M, Pellacani A, Bergomi S, Carpana E, Rabitti T, Lasagni P (1992) Residue determination for some products used against Varroa infestation 
in bees. Apidologie 23:257-272.https://doi.org/10. 1051/apido:19920309

Loftus JC, Smith ML, Seeley TD (2016) How Honey Bee Colonies Survive in the Wild: Testing the Importance of Small Nests and Frequent Swarming. PLoS One 11:e0150362. https://doi.org/10.1371/journal. pone. 0150362

Martin S, Holland K, Murray M (1997) Non-reproduction in the honeybee mite Varroa jacobsoni. Experimental and Applied Acarology 21:539-549. https://doi. org/10.1023/A:1018492231639

Martin C, Provost E, Bagneres A-G, Roux M, Clement J-L, Le Conte Y (2002) Potential mechanism for detection by Apis mellifera of the parasitic mite Varroa destructor inside sealed brood cells. Physiol Entomol 27:175-188. https://doi.org/10.1046/j.1365-3032. 2002.00284.x

Martin SJ (1994) Ontogenesis of the mite Varroa jacobsoni Oud. in worker brood of the honeybee Apis mellifera L. under natural conditions. Exp Appl Acarol 18:87-100. https://doi.org/10.1007/BF00055033

Martin SJ, Hawkins GP, Brettell LE, Reece N, Correia-Oliveira ME, Allsopp $\mathrm{MH}$ (2020) Varroa destructor reproduction and cell re-capping in mite-resistant Apis mellifera populations. Apidologie 51:369-381. https://doi.org/10.1007/ s13592-019-00721-9

Milani N (1999) The resistance of Varroa jacobsoni Oud. to acaricides. Apidologie 30:229-234. https://doi.org/10.1051/apido:19990211

Mondet F, Kim SH, Miranda JR de, Beslay D, Le Conte Y, Mercer AR (2016) Specific Cues Associated With Honey Bee Social Defence against Varroa destructor Infested Brood. Sci Rep 6:25444. https://doi.org/10.1038/srep25444

Mondet F, Parejo M, Meixner MD, Costa C, Kryger P, Andonov S, Servin B, Basso B, Bieńkowska M, Bigio G, Căuia E, Cebotari V, Dahle B, Dražić MM, Hatjina F, Kovačić M, Kretavicius J, Lima AS, Panasiuk B, Pinto MA, Uzunov A, Wilde J, Büchler R (2020a) Evaluation of Suppressed Mite Reproduction (SMR) Reveals Potential for Varroa Resistance in European Honey Bees (Apis mellifera L.). Insects 11:595. https://doi.org/10.3390/ insects 11090595

Mondet F, Beaurepaire A, McAfee A, Locke B, Alaux C, Blanchard S, Danka B, Conte Le Y (2020b) Honey bee survival mechanisms against the parasite Varroa destructor: a systematic review of phenotypic and genomic research efforts International Journal for Parasitology 50:433-447. https://doi. org/10.1016/j.ijpara.2020.03.005

Mondet F, Blanchard S, Barthes N, Beslay D, Bordier C, Costagliola G, Hervé MR, Lapeyre B, Kim SH, Basso B, Mercer AR, Le Conte Y (2021) Chemical detection triggers honey bee defense against a destructive parasitic threat. Nat Chem Biol:1-7. https://doi.org/10.1038/s41589-020-00720-3

Nazzi F, Della Vedova G, D’Agaro M (2004) A semiochemical from brood cells infested by Varroa destructor triggers hygienic behaviour in Apis mellifera. Apidologie 35:65-70. https://doi.org/ 10.1051/apido:2003065

Oddie M, Büchler R, Dahle B, Kovacic M, Le Conte Y, Locke B, Miranda JR de, Mondet F, Neumann P (2018) Rapid parallel evolution overcomes global honey bee parasite. Sci Rep 8:7704. https://doi.org/ 10.1038/s41598-018-26001-7

Oddie M, Dahle B, Neumann P (2017) Norwegian honey bees surviving Varroa destructor mite infestations by means of natural selection. Peer J 5:e3956. https://doi. org/10.7717/peerj.3956

Oddie M, Burke A, Dahle B, Le Conte Y, Mondet F, Locke B (2021) Reproductive success of the parasitic mite (Varroa destructor) is lower in honeybee colonies that target infested cells with recapping. Sci Rep 11:9133. https://doi.org/10.1038/ s41598-021-88592-y

Pietropaoli M, Formato G (2018) Liquid formic acid $60 \%$ to control varroa mites (Varroa destructor) in honey bee colonies (Apis mellifera): protocol evaluation. J Apic Res 57:300-307. https://doi.org/ 10.1080/00218839.2017.1376767

Rinderer TE, Harris JW, Hunt GJ, Guzman LI de (2010) Breeding for resistance to Varroa destructor in North America. Apidologie 41:409-424. https:// doi.org/10.1051/apido/2010015

Rosenkranz P, Garrido C (2004) Volatiles of the honey bee larva initiate oogenesis in the parasitic mite Varroa destructor. Evolutionary, Mechanistic and Environmental Approaches to Chemically-Mediated Interactions 14:193-197. https://doi.org/10. 1007/s00049-004-0278-0

Schöning C, Gisder S, Geiselhardt S, Kretschmann I, Bienefeld K, Hilker M, Genersch E (2012) Evidence for damage-dependent hygienic behaviour towards Varroa destructor-parasitised brood in the western honey bee, Apis mellifera. Journal of Experimental Biology 215:264-271. https://doi. org/10.1242/jeb.062562

Spivak M (1996) Honey bee hygienic behavior and defense against Varroa jacobsoni. Apidologie, 27(4), 245-260. Apidologie 27:245-260. https://doi.org/10.1051/ APIDO:19960407

Spivak M, Danka RG (2020) Perspectives on hygienic behavior in Apis mellifera and other social insects. Apidologie:1-16. https://doi.org/10.1007/ s 13592-020-00784-z

Strachecka A, Paleolog J, Olszewski K, Borsuk G (2012) Influence of Amitraz and Oxalic Acid on the Cuticle Proteolytic System of Apis mellifera L. Workers. Insects 3:821-832. https://doi.org/10. 3390/insects3030821

Traynor KS, Mondet F, Miranda JR de, Techer M, Kowallik V, Oddie MAY, Chantawannakul P, McAfee A (2020) Varroa destructor: A Complex Parasite, Crippling Honey Bees Worldwide. Trends in Parasitology 36:592-606. https://doi.org/10.1016/j.pt.2020.04.004

van Alphen JJM, Fernhout B (2019) A small shift in VSH-gene frequency instead of rapid parallel 
evolution in bees. A comment on Oddie et al. 2018. PeerJ Preprints. https://doi.org/10.7287/ peerj.preprints.27938v2

van Alphen JJM, Fernhout BJ (2020) Natural selection, selective breeding, and the evolution of resistance of honeybees (Apis mellifera) against Varroa. Zoological Lett 6:1-20. https://doi.org/10.1186/ s40851-020-00158-4

Villa JD, Danka RG, Harris JW (2009) Simplified methods of evaluating colonies for levels of Varroa Sensitive Hygiene (VSH). Journal of Apicultural Research 48:162-167. https://doi.org/10.3896/IBRA.1.48.3.03

Wagoner K, Spivak M, Hefetz A, Reams T, Rueppell O (2019) Stock-specific chemical brood signals are induced by Varroa and Deformed Wing
Virus, and elicit hygienic response in the honey bee. Sci Rep 9:8753. https://doi.org/10.1038/ s41598-019-45008-2

Wagoner KM, Spivak M, Rueppell O (2018) Brood Affects Hygienic Behavior in the Honey Bee (Hymenoptera: Apidae). J Econ Entomol 111:2520-2530. https://doi.org/10.1093/jee/toy266

Wallner K (1999) Varroacides and their residues in bee products. Apidologie 30:235-248. https://doi.org/ 10.1051/apido: 19990212

Publisher's Note Springer Nature remains neutral with regard to jurisdictional claims in published maps and institutional affiliations. 